\title{
Water Dynamics under Drip Irrigation to Proper Manage Water Use in Arid Zone
}

\author{
Siguibnoma Kevin Landry Ouédraogo, Marcel Bawindsom Kébré, Francois Zougmoré
}

Laboratoire de Matériaux et Environnement, Université Joseph KI-ZERBO, Ouagadougou, Burkina Faso

Email: siguibnoma@gmail.com

How to cite this paper: Ouédraogo, S.K.L., Kébré, M.B. and Zougmoré, F. (2021) Water Dynamics under Drip Irrigation to Proper Manage Water Use in Arid Zone. Journal of Agricultural Chemistry and Environment, 10, 57-68.

https://doi.org/10.4236/jacen.2021.101004

Received: December 1, 2020

Accepted: January 15, 2021

Published: January 18, 2021

Copyright () 2021 by author(s) and Scientific Research Publishing Inc. This work is licensed under the Creative Commons Attribution International License (CC BY 4.0).

http://creativecommons.org/licenses/by/4.0/

\begin{abstract}
The water resources reduction due to climate changes and also population increase, have contributed to increasing the constraint on water disponibility and accessibility. In the agricultural field, we need moderate soil and water resources management. This work aims to simulate water dynamics in soil under drip irrigation system in arid regions to better manage irrigation water. Simulations are done with soil physical properties of Burkina Faso. We assess maize plant water requirements for the whole growing season. With Hydrus $2 \mathrm{D}$, we simulate water supply in the soil column. We assign atmospheric conditions on the top of the domain, zero flux of water on the lateral sides, and free drainage on the bottom boundary domain. We perform many irrigation events to analyze wetting pattern distribution around the emitter, which allowed us to contain the amount of irrigation water applied, only around the area dominated by roots, and then reduce water losses that roots cannot uptake. According to the different growing stages of the maize crop, we choose proper irrigation duration and frequency, and suggest irrigation schedule for the whole growing season.
\end{abstract}

\section{Keywords}

Drip Irrigation, Water Dynamics, Hydrus (2D/3D), Water Management

\section{Introduction}

The countries of sub-Saharan Africa like the other countries in the world face multiple problems linked to climate changes. These problems are: rainfall modification, season shift and the increase of extreme meteorological events such as drought or flood particularly in arid or semi-arid regions like Burkina Faso, which affect considerably water and soil resources. Water resources reduction due to climate changes, and also population increase, have contributed to in- 
creasing constraint on water supply and accessibility which were already an important problem in Sahelian countries. Furthermore, we have self-food sufficiency problem. We will need irrigated agriculture to produce more food with less water and without deteriorating soil and water resources. Drip irrigation technology can face the challenge [1] [2]. It allows water and solute use more efficiently, reduces losses by allowing accurate supply of water and solutes in the crop base [3]. This work is performed in order to help farmers to improve water and soil management. The main objective of this study is to use Hydrus 2D to analyze water dynamics under drip irrigation in arid soil in Burkina Faso and guide farmers in the water management depending on the specific soil physical properties. The specific objectives are: 1) forecast infiltration, redistribution and evaporation in a soil column with Hydrus 2D;2) forecast water losses by reducing the amount of irrigation water which reaches region unexplored by the roots; 3 ) and suggest efficient water use model based on the crop used. Numerical simulation is a fast and efficient tool to study optimal management of drip irrigation technic [2] [4]. Several studies have shown the importance of numerical modeling to design and manage irrigation systems and ferti-irrigation too [5]-[18].

\section{Methods and Materials}

\subsection{Drip Irrigation}

It enables water supplying into the soil, directly in the plant base with small regular amounts of water. Drip irrigation improves water use efficiency, plants growth and production yield. It also improves the application of fertilizers and solutes, it reduces the risk of salinity, weeds and energy needs [19]. Drip irrigation is the most efficient system for crop, vegetables, and fruit trees irrigation [20]. In arid regions or semi-arid regions, due to water scarcity and the increasingly use of water in agriculture drip irrigation is very important to ensure more efficient management of water resources. We distinguish surface drip irrigation system, sub-surface drip irrigation system and family drip irrigation. We called family drip irrigation system, a drip irrigation perform especially for family production, operating in small area between 500 to $1000 \mathrm{~m}^{2}$. It is ideal for rural zones, where there is a water scarcity or water supply is limited, moreover no competency or expertize is required [21].

\subsection{Hydrus 2D Software}

Hydrus is a worldwide known software used in many fields linked to soil sciences. The software gives a modelisation scheme that allows to analyze water flow, the movement of solutes and heat in variably-saturated media [22]. Hydrus can be used as a design tool to study and design drip irrigation system management. Hydrus has been used successfully to simulate water flow under drip irrigation [4] [6] [22] [23]. The Hydrus program numerically solves the equation for water flow, heat and solutes transport [4] [6] [23]. The governing equation in 
two dimension $(\mathrm{X}, \mathrm{Z})$ for water flow in a variably-saturated porous media included in Hydrus is given in Equation (1) as:

$$
\frac{\partial \theta}{\partial t}=\frac{\partial}{\partial x}\left[K(h) \frac{\partial h}{\partial x}\right]+\frac{\partial}{\partial z}\left[K(h) \frac{\partial h}{\partial z}+K(h)\right]-S(h)
$$

where $x, z$ are the spatial coordinates $(\mathrm{m}) ; h$ is the soil water pressure head $(\mathrm{m}) ; t$ is the time $(\mathrm{s}) ; K$ is the hydraulic conductivity function $\left(\mathrm{m} \cdot \mathrm{s}^{-1}\right) ; \theta$ is the volumetric water content $\left(\mathrm{m} \cdot \mathrm{m}^{-3}\right)$ and $S$ is the root water uptake term $\left(\mathrm{s}^{-1}\right)$. The hydraulic conductivity function is given by the van-Genuchten (1980)-Mualem (1976) relationnships in Equation (2).

$$
K_{r}(\theta)=\left(\frac{\theta-\theta_{r}}{\theta_{\text {sat }}-\theta_{r}}\right)^{1 / 2}\left[1-\left[1-\left(\frac{\theta-\theta_{r}}{\theta_{\text {sat }}-\theta_{r}}\right)^{1 / m}\right]^{m}\right]^{2}
$$

where $\theta$ is the volumetric water content; $\theta_{\text {sat }}$ is the saturated volumetric water content $\left(\mathrm{m} \cdot \mathrm{m}^{-3}\right) ; \theta_{r}$ is the residual water content $\left(\mathrm{m} \cdot \mathrm{m}^{-3}\right)$ and $m$ is a shape parameter given by the water retention curve suggested by van-Genuchten (1980).

$$
S_{e}(h)=\frac{\theta(h)-\theta_{r}}{\theta_{\text {sat }}-\theta_{r}}=\left[1+(\alpha h)^{n}\right]^{-m}
$$

Irrigation was conducted with constant flux, with water application rate of 1 $1 \cdot \mathrm{h}^{-1} \cdot \mathrm{m}^{-1}$ and emitter radius $r=1 \mathrm{~cm}$. The water flux to supply is determined by Equation (4):

$$
q=\frac{Q}{2 \pi r}=\frac{1000 \mathrm{~cm}^{3} \cdot \mathrm{h}^{-1}}{2 \pi \times 1 \mathrm{~cm} \times 100 \mathrm{~cm}}=1.59 \mathrm{~cm} \cdot \mathrm{h}^{-1}
$$

$q$ is the water flux $\left(\mathrm{cm} \cdot \mathrm{h}^{-1}\right) ; Q$ is the emitter discharge rate $\left(1 \cdot \mathrm{h}^{-1} \cdot \mathrm{m}^{-1}\right)$ and $r$ the emitter radius $(\mathrm{cm})$.

\subsection{Soil Physic Properties Used for Simulation}

The soil physic properties used to perform the simulations, come from the west Bobo Dioulasso city. This soil has general characteristics to many soils of Burkina Faso particulary in the Sahelian zone [24]. A complete characterization has been done by [24] to determine physic, morphologic and hydrodynamic properties. Soil was dug with 1 meter depth on $2.5 \mathrm{~m} \times 2 \mathrm{~m}$ area. According to depth 3 layers was determined as followed: from 0 to $30 \mathrm{~cm}$ superficial layer; from $30 \mathrm{~cm}$ to $70 \mathrm{~cm}$ the middle layer; and deep layer from $70 \mathrm{~cm}$ to $100 \mathrm{~cm}$. The superficial layer $(30 \mathrm{~cm}$ depth) is used in this study. Table 1 shows the properties used for the modelisation.

Table 1. Soil hydraulic properties used for simulations [24].

\begin{tabular}{ccccccc}
\hline Parameters & $\theta_{r}$ & $\theta_{\text {sat }}$ & $\alpha$ & $n$ & $K_{s}$ & 1 \\
\hline Values & 0 & 0.3655 & 0.107483 & 1.3922 & 268.932 & 0.5 \\
Units & $\mathrm{m} \cdot \mathrm{m}^{-3}$ & $\mathrm{~m} \cdot \mathrm{m}^{-3}$ & $\mathrm{~cm}^{-1}$ & - & $\mathrm{cm} \cdot$ day $^{-1}$ & - \\
\hline
\end{tabular}




\subsection{Field of Study and Boundary Conditions}

The transport domain is a vertical two dimensional plan (XZ) of the soil layer. We assume that the soil is completely dry before the simulations and the initial water content is assume to be zero, $\theta_{i}=0$. The boundaries conditions counted during the simulation are shown in Figure 1 and presented in Table 2. We consider atmospheric conditions on the top of the domain; on the lateral sides far of $80 \mathrm{~cm}$ we assign zero flux of water; on the bottom boundary of the domain we apply free drainage that allows water which reach the bottom boundary to go free away.

\subsection{The Maize Crop}

As an application, we used the maize crop to optimize water supply under drip irrigation. The species of the maize crop used is the intermediate variety with a production duration of fourteen weeks. In Figure 2, we show the schedule to grow the maize suggested by the Ministry of Agriculture, Hydraulic and Fisheries Resources of Burkina Faso. It allows to assess the plant water requirements depending on the growth stage. The water requirements was calculated from potential evapotranspiration $\left(E T_{0}\right)$ data of the Meteorology Department of Burkina Faso. $E T_{0}$ was calculated with the Penman-Monthei method.

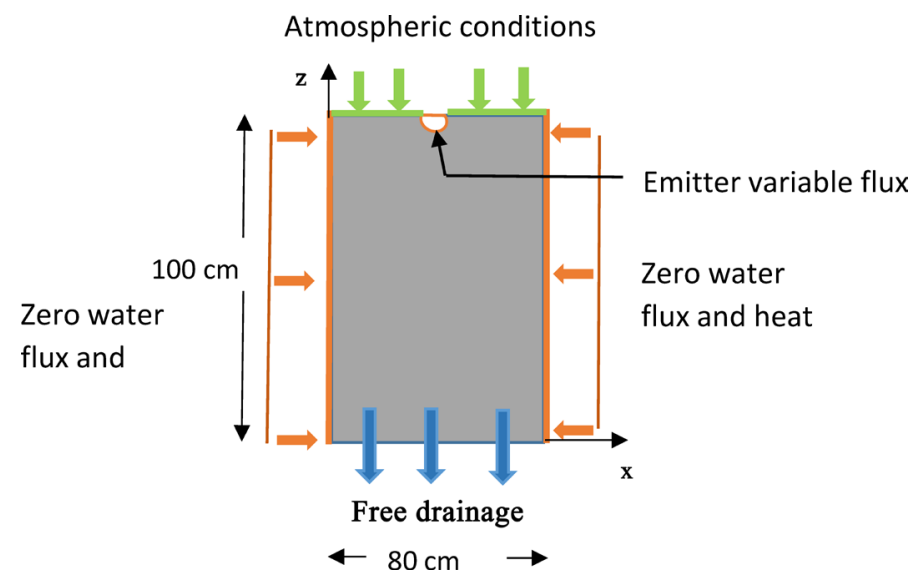

Figure 1. Transport domain and boundary conditions.

Table 2. Boundaries conditions assigned to the domain.

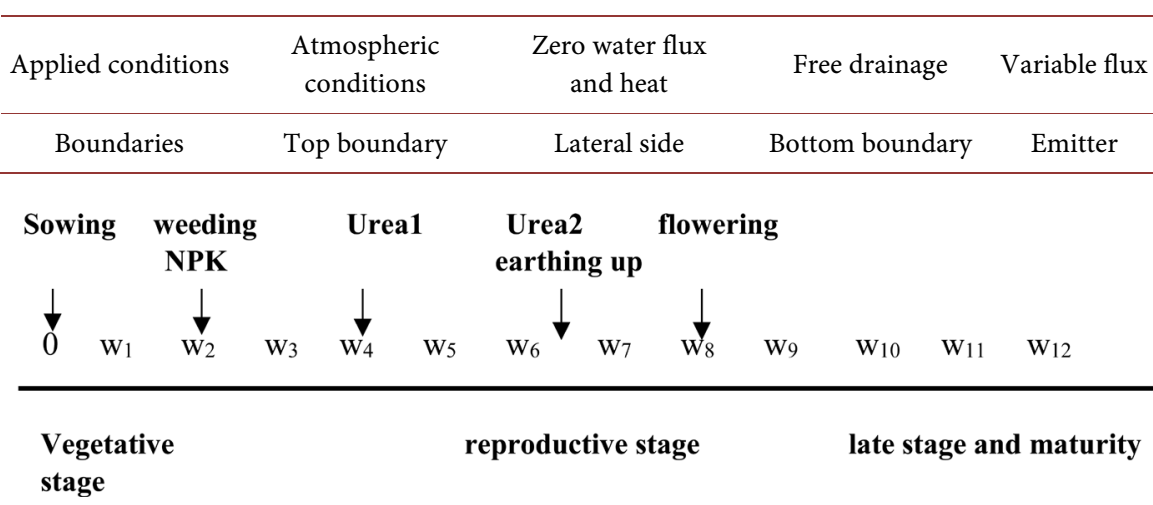

Figure 2. Maize crop schedule suggest by the ministry of agricluture. 


\subsection{Water Requirements for Irrigation}

Irrigation scheduling is done at $100 \%$ of crop evapotranspiration $\left(E T_{c}\right)$. The values of potential evapotranspiration used to calculate the crop evapotranspiration are those collected by the meteorology agency. The water requirements to supply climatic needs $\left(E T_{c}\right)$ was determined Equation (5), and the different values are shown in Table 3.

$$
E T_{c}=E T_{0} \times K_{c} .
$$

where $E T_{c}$ is the crop water evapotranspiration (mm/day); $E T_{0}$ the potential evapotranspiration ( $\mathrm{mm} /$ day) and $K_{c}$ is the dimensionless maize crop coefficient depending on plant growth.

\section{Results and Discussion}

We perform simulation according to each growing stage and we show some of theses results.

\subsection{Initial Stage of Growing}

Considering $1 \mathrm{~mm} /$ day rain depth like 1 liter volume of water spreaded in an area of $1 \mathrm{~m}^{-2}$, for the initial stage an irrigation event will end off after 2.5 hours of water application with flow rate of $11 \cdot \mathrm{h}^{-1} \cdot \mathrm{m}^{-1}$ to supply a crop evapotranspiration value of $2.6684 \mathrm{~mm} /$ day. Assuming a daily water supply frequency. Figure 3 shows the water content distribution into the soil at $t=1$ hour corresponding to first day and at $t=120$ hours five days later. We notice water content value of $\theta$ $=0.197 \mathrm{~m}^{3} \cdot \mathrm{m}^{-3}$ at $13 \mathrm{~cm}$ around the emitter. This value exceeds considerably the water requirements just needed for the first days of germination. After many attempts in order to reduce the water flux, we will contain the length of the water content distribution around the emitter by spacing water flow supplying. Finally to manage water flow supplying for the initial stage, we assume 3 days frequency, which reduce water losses. We also avoid a hydric stress to the plant. We present in Figure 4. The water content distribution around the emitter according to the new frequency adopted.

\subsection{Growth Stage}

At this step, the initial condition for water content and temperature are taken to be equal to the final water content and temperature in the initial stage. Furthermore, $E T_{c}=6.3176 \mathrm{~mm} /$ day, thus we will need approximatively 6 hours of

Table 3. Water requirements and crop coefficient.

\begin{tabular}{ccccc}
\hline Growth cycle & Initial stage & Growth stage & Middle stage & Harvest stage \\
\hline Duration (weeks) & $0-3$ & $3-6$ & $6-9$ & $9-14$ \\
$K_{c}$ & 0.40 & 0.80 & 1.15 & 0.70 \\
$E T_{0}$ & 6.671 & 7.897 & 6.2858 & 6.5644 \\
$E T_{c}$ & 2.6684 & 6.3176 & 7.2287 & 4.5951 \\
\hline
\end{tabular}




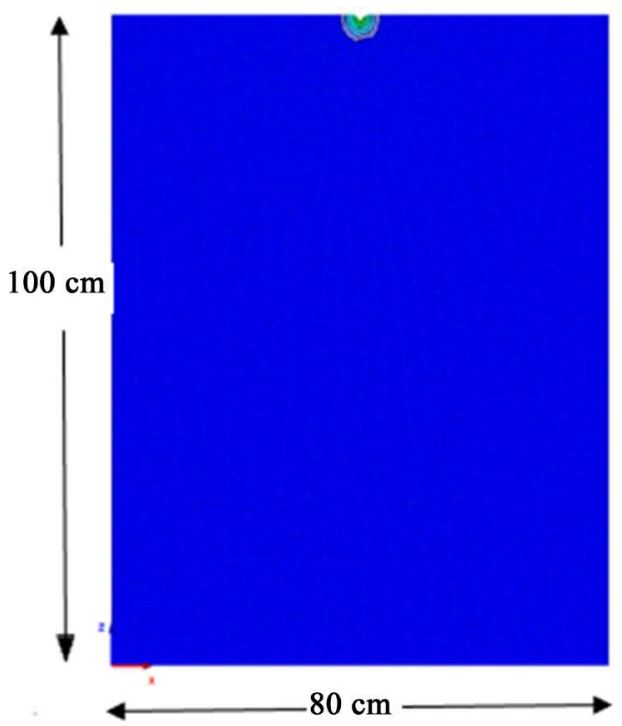

(a)

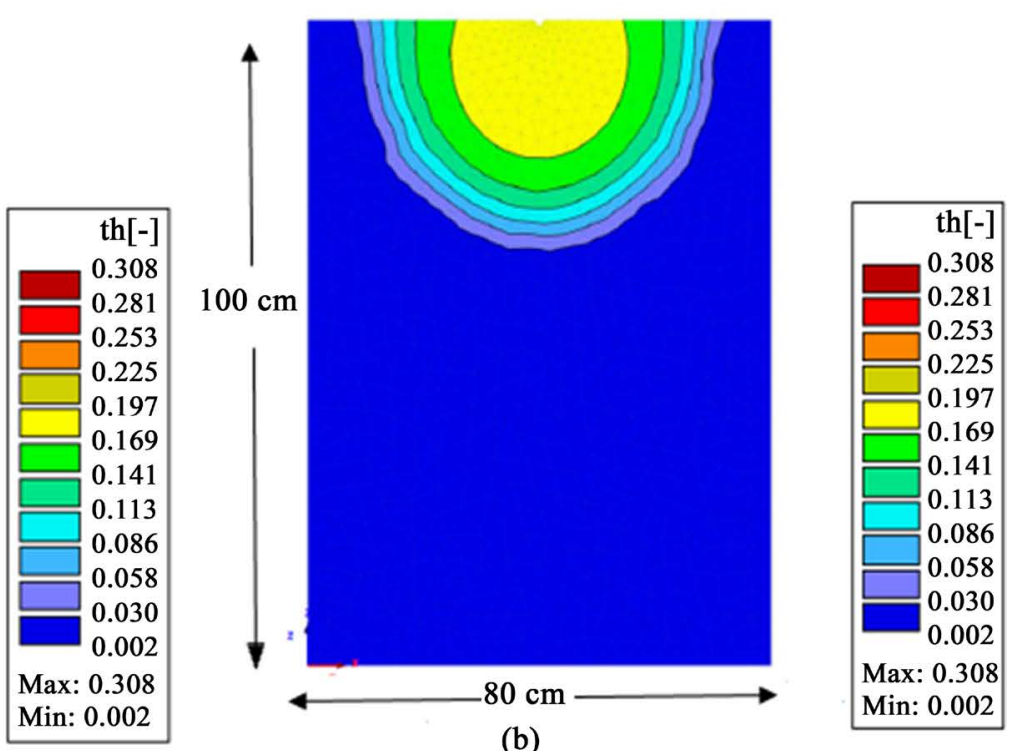

(b)

Figure 3. Water content distribution for initial stage of growing at $t=1$ hour (a) and at $t=120$ hours (b).

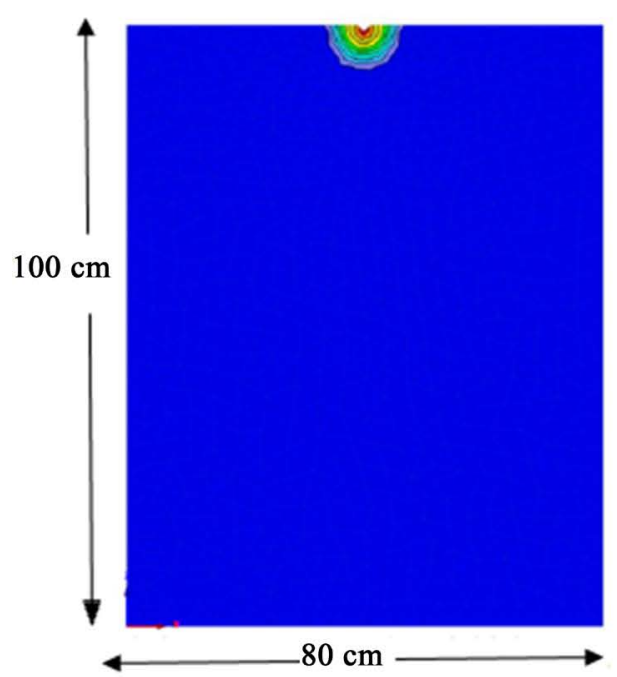

(a)

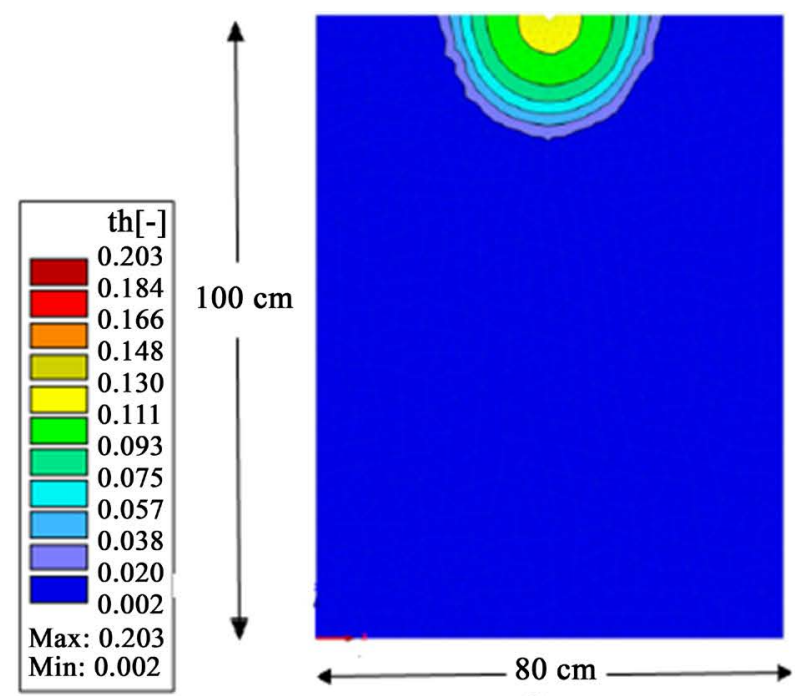

(b)

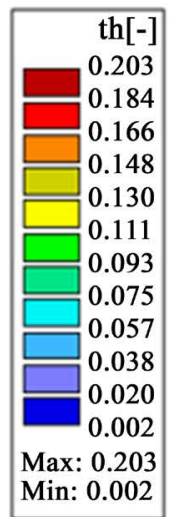

Figure 4. (a) Water content distribution 1st day, and 21 day later (b), irrigation frequency 3 day.

irrigation to supply the plant water requirements. In Figure 5, we show the water content distribution corresponding to the first experiments.

For water content value $\theta=0.113 \mathrm{~m}^{3} \cdot \mathrm{m}^{-3}$, the wetted area extend to $14 \mathrm{~cm}$ around the emitter concerning the first day. At the last day of the simulation the wetted area reach $35 \mathrm{~cm}$ around the emitter for the same water content. The area reached by the water strongly exceed the area hold by roots. We can then reduce the quantities of water supplied by keeping the wetted area to the zone colonized by roots. The irrigation frequency kept is 3 days, we obtain a wetted zone of 25 $\mathrm{cm}$ around the emitter with water content $\theta=0.111 \mathrm{~m}^{3} \cdot \mathrm{m}^{-3}$. The water volume is restricted to the optimum volume hold by the roots. In Figure 6 we present the water content new distribution for the new frequency chosed. 
For the last two growth stages, we take into account root water uptake parameter to perfom simulations.

\subsection{Middle-Stage of Growth}

At this growth stage, crop water requirements raised again with $E T_{c}=7.2287$ $\mathrm{mm} /$ day. An irrigation event will take approximately 7 hours per day to supply plant water requirement. The initial water content and initial temperature correspond respectively to the final water content and temperature of the previous growth stage. Figure 7 shows the corresponding water content distribution in the soil.

We notice that the wetting zone reach an area of $30 \mathrm{~cm}$ around the emitter concerning the first day and $36 \mathrm{~cm}$ area at the 21 st day of the stage. The available water in soil after roots uptake is so important. At the end of the simulation $\theta=$

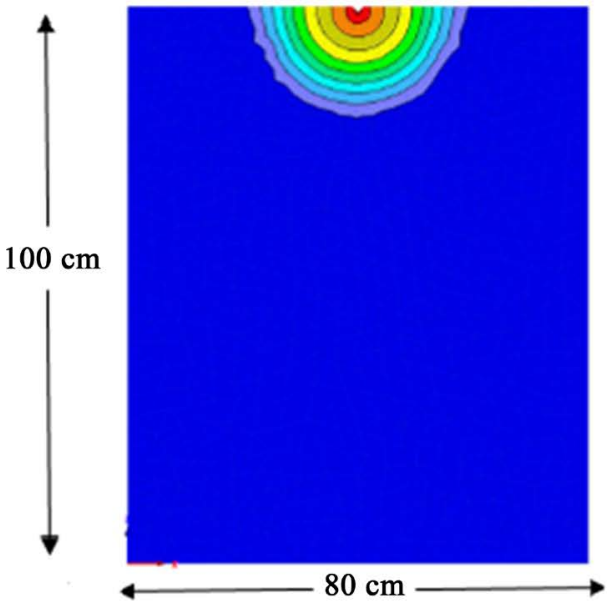

(a)

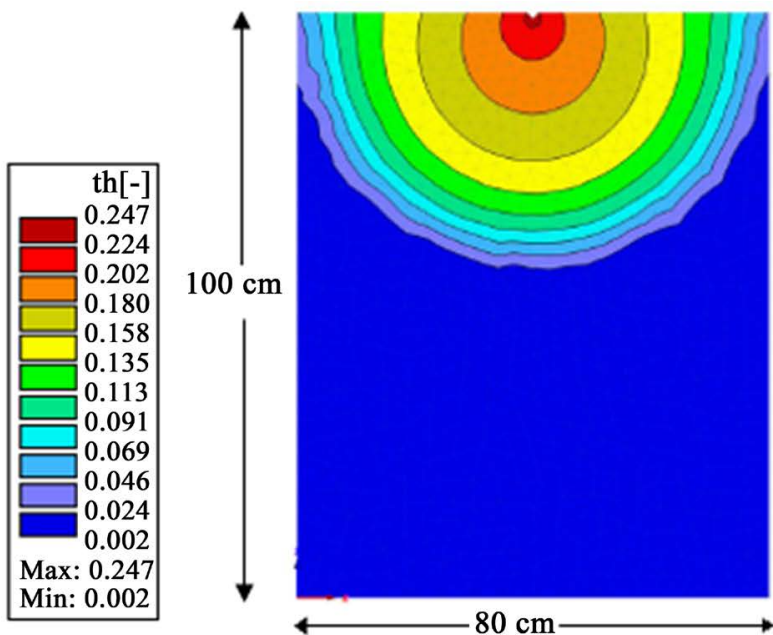

(b)

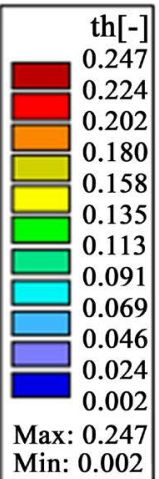

Figure 5. (a) Water content distribution 1st day, and 21 day later (b), daily irrigation frequency.

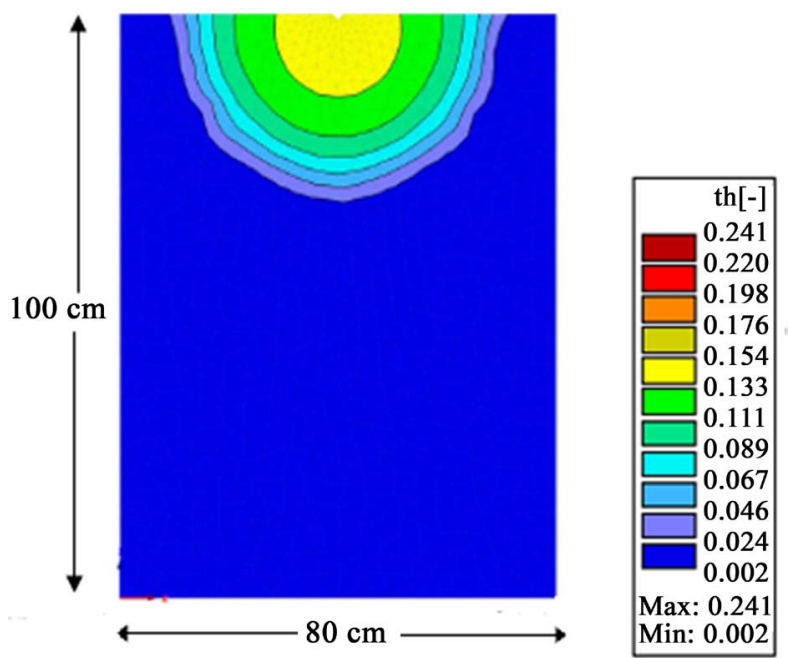

Figure 6. Water content distribution, growth stage at $t=21$ day, irrigation frequency 3 days. 
$0.124 \mathrm{~m}^{3} \cdot \mathrm{m}^{-3}$ for $36 \mathrm{~cm}$ depth. To reduce the quantities of water used to simulate this phase, we space the water supplying. And then reduce water stored in soil and the quantities of water non-uptake. To avoid water stress condition by using less water to supply the plant, we chose an irrigation frequency of 3 days. Figure 8. The water content distribution in the soil with the new frequency.

\subsection{Harvest Stage}

To compare with the middle-stage, we get a diminution of water requirements with $E T_{c}=4.5951 /$ day. Nevertheless, to supply crop water requirements, an irrigation event will take 5 hours. We simulated water flux to supply during 35 days. In Figure 9, the wetting zone extend to $14 \mathrm{~cm}$ depth at the first day of water

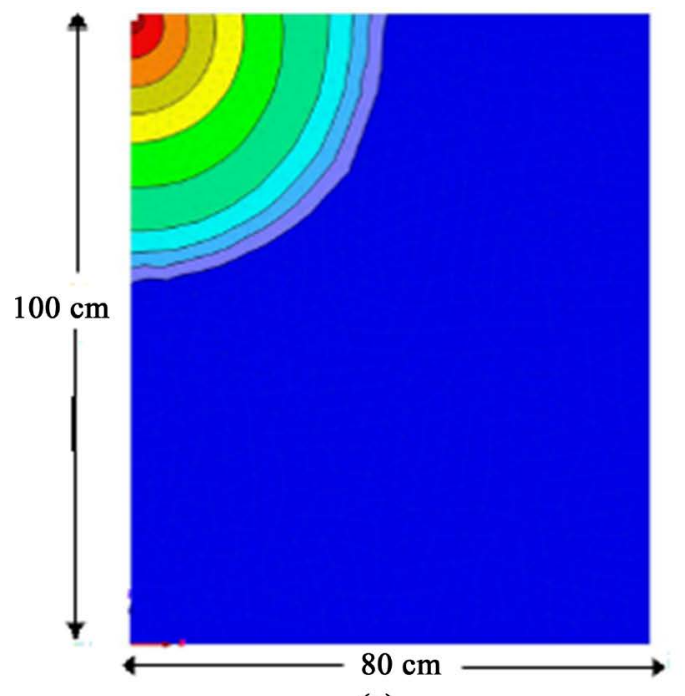

(a)

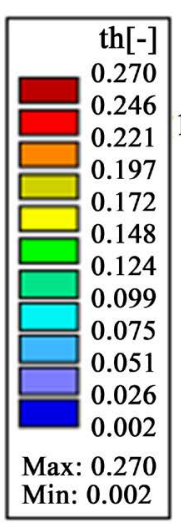

Min: 0.002

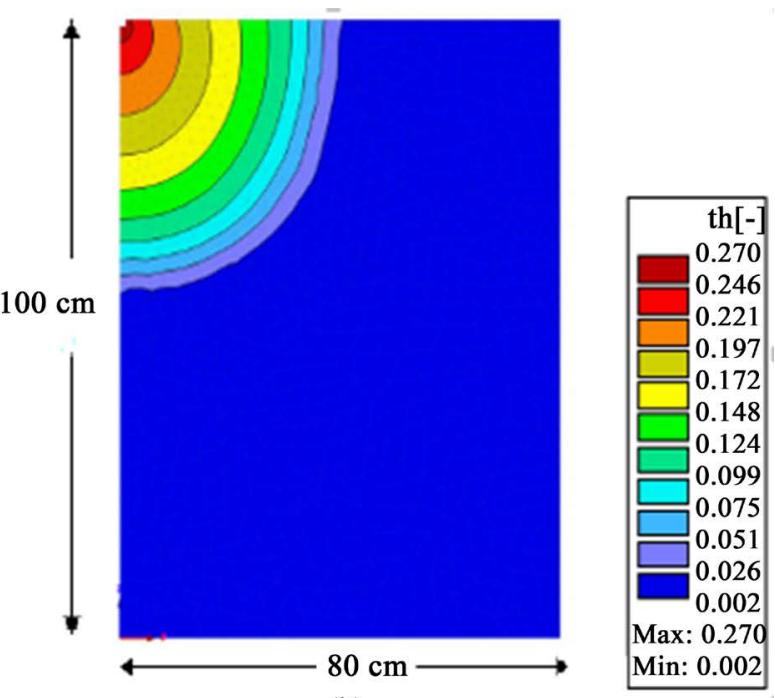

(b)

Figure 7. Water content distribution : middle-stage of growth, daily irrigation frequency, (a) $t=1$ day and (b) $t=21$ day later.

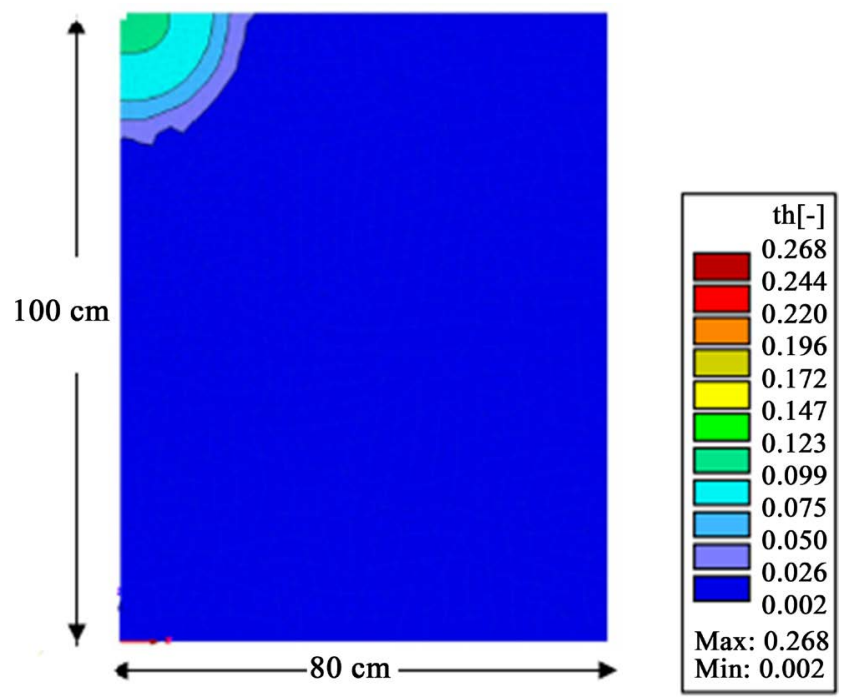

Figure 8. Water content distribution, middle-stage of growth at $t=21$ st day, irrigation frequency 3 days. 
supplying and reach $25 \mathrm{~cm}$ depth at 30th day and remain at this depth until 35th day. Analyzing the wetting zone on the 35th day we get an important available water content in $25 \mathrm{~cm}$ area around the emitter. For better use of water provide to the maize crop, we will space water supplying. Adopting 3 days of irrigation frequency, we present the corresponding wetting shape in the soil. Water content is about $\theta=0.068 \mathrm{~m}^{3} \cdot \mathrm{m}^{-3}$ at $12 \mathrm{~cm}$ around the emitter that shows a reduction of available water. We keep this frequency to supply water at the harvest stage. Figure 10 show the water content distribution for new frequency adopted. The different simulations lead us to manage water supplying depending on

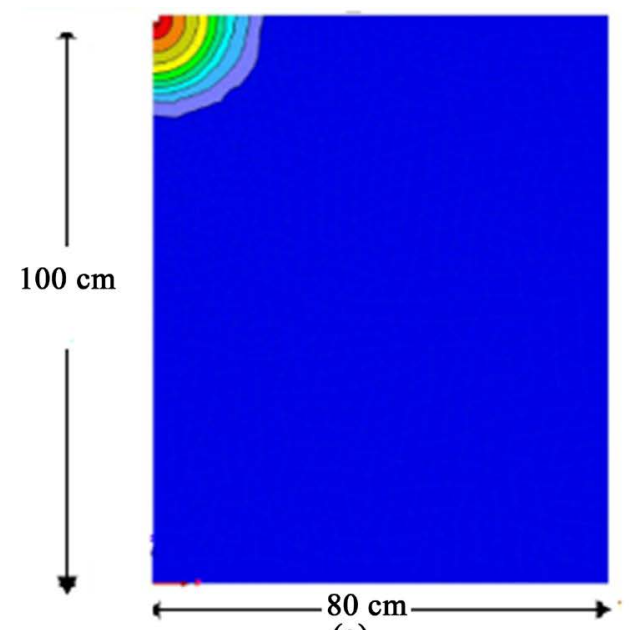

(a)

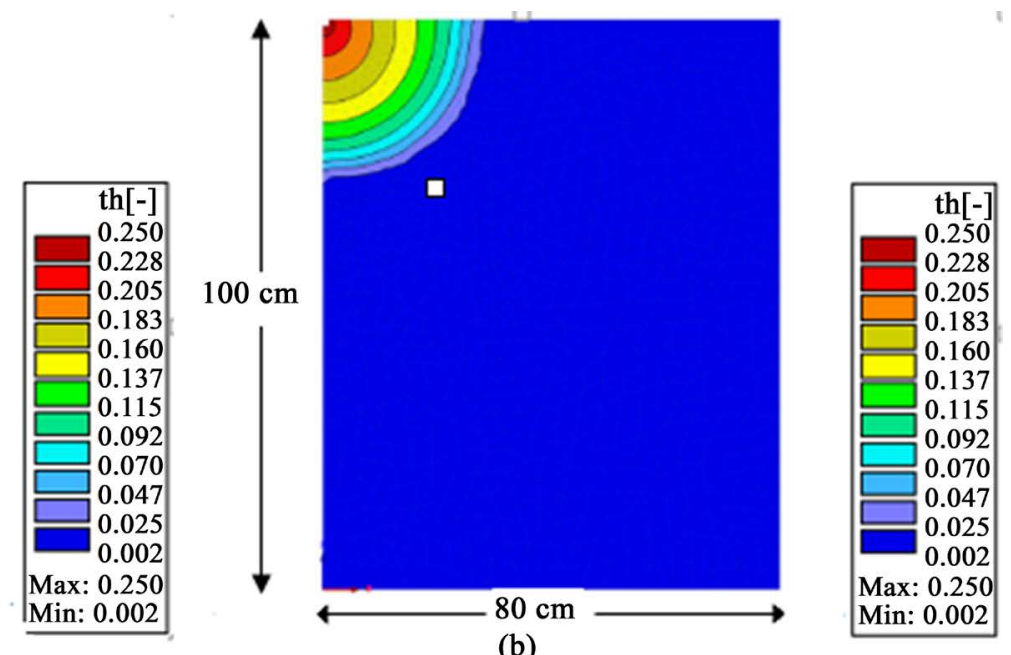

(b)

Figure 9. Water content distibution, harvest stage, daily frequency; (a) $t=1$ st day, (b) at $t=35$ th later.

Table 4. Irrigation scheduling of maize cycle production for fourteen weeks.

\begin{tabular}{cccccc}
\hline & Growth stage & Initial stage & Growth stage & Middle stage & Harvest stage \\
\hline Flow rate & Irrigation duration & 2.5 hours & 6 hours & 7 hours & 5 hours \\
$Q=1 \mathrm{l} \cdot \mathrm{h}^{-1} \cdot \mathrm{m}^{-1}$ & Frequency & 3 days & 3 days & 3 days & 3 days \\
\hline
\end{tabular}

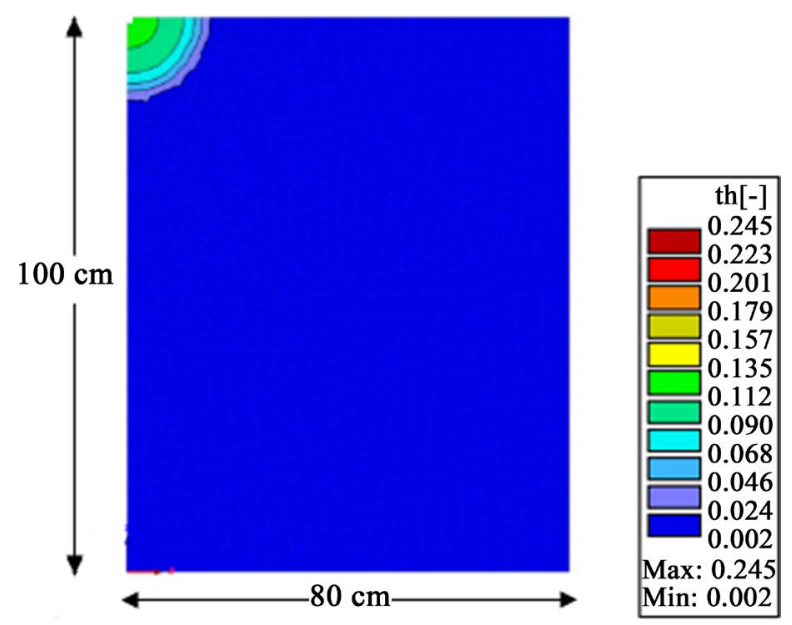

Figure 10. Water content distribution, harvest stage at $t=35$ th day, irrigation frequency 3 days. 
different growth stage, to compensate crop water requirements. Taking into account all these irrigation frequencies chosen, we suggest an irrigation scheduling in Table 4.

\section{Conclusion}

The purpose of this study was to analyze water dynamics in soil under drip irrigation in arid zone and, hence to manage properly irrigation water according to soil physical properties. Therefore we assessed water requirements $500 \mathrm{~mm} /$ day to supply for maize crop production and carried out many simulations with Hydrus $2 \mathrm{D}$. The study of the wetting zone dimensions, allowed us to schedule water supply by taking irrigation duration and frequency according to crop growth stages. So we restricted the amount of irrigation water applied around the root zone and then reduced also water losses. Finally, we suggest irrigation scheduling for the whole maize growing season. Nevertheless, it could be interesting to carry out some experiments to assess the crop yield depending on the amount of irrigation water used, in order to enhance production yield and water management under drip irrigation.

\section{Acknowledgements}

The authors wish to thank Dr Kébré B. Marcel for determining soil physical properties and his support to this study. The authors acknowledge Burkina Faso National Meteorological Agency for meteorological data.

\section{Conflicts of Interest}

The authors declare no conflicts of interest regarding the publication of this paper.

\section{References}

[1] Subbaiah, R. and Mashura, H.H. (2013) Modeling for Predicting Soil Wetting Radius under Point Source Surface Trickle Irrigation. Agricultural Engineering International: CIGR Journal, 15, 1-10.

[2] Seidel, S.J., Schutze, N., Fahle, M., Mailhol, J.-C. and Ruelle, P. (2015) Optimal Irrigation Scheduling, Irrigation Control and Drip Line Layout to Increase Water Productivity and Profit in Subsurface Drip-Irrigated Agriculture. Irrigation and Drainage, 64, 501-518. https://doi.org/10.1002/ird.1926

[3] Wang, Z., Li, J. and Li, Y. (2014) Simulation of Nitrate Leaching under Varying Drip System Uniformities and Precipitation Patterns during the Growing Season of Maize in the North China Plain. Agricultural Water Management, 142, 19-28. https://doi.org/10.1016/j.agwat.2014.04.013

[4] Skaggs, T.H., Trout, T.J., Simunek, J. and Shouse, P.J. (2004) Comparison of HYDRUS-2D Simulations of Drip Irrigation with Experimental Observations. Journal of Irrigation and Drainage Engineering, 130, 304-310. https://doi.org/10.1061/(ASCE)0733-9437(2004)130:4(304)

[5] Cote, C.M., Bristow, K.L., Charlesworth, P.B., Cook, F. J. and Thorburn, P.J. (2003) Analysis of Soil Wetting and Solute Transport in Subsurface Trickle Irrigation. Ir 
rigation Science, 22, 143-156. https://doi.org/10.1007/s00271-003-0080-8

[6] Lazarovitch, N., Simunek, J. and Shani, U. (2005) System Dependent Boundary Condition for Water Flow from Subsurface Source. Soil Science Society of America Journal, 69, 46-50. https://doi.org/10.2136/sssaj2005.0046

[7] Gardenas, A.I., Hopmans, J.W., Hanson, B.R. and Simunek, J. (2005) Two-Dimensional Modeling of Nitrate Leaching for Various Fertigation Scenarios under Micro Irrigation. Agricultural Water Management, 74, 219-242. https://doi.org/10.1016/j.agwat.2004.11.011

[8] Hanson, B.R., Simunek, J. and Hopmans, J.W. (2006) Evaluation of Urea- Ammonium-Nitrate Fertigation with Drip Irrigation Using Numerical Modeling. Agricultural Water Management, 86, 102-113. https://doi.org/10.1016/j.agwat.2006.06.013

[9] Ajdary, K., Singh, D.K., Singh, A.K. and Kohanna, M. (2007) Modelling of Nitrogen Leaching from Experimental Onion Field under Drip Fergation. Agricultural Water Management, 89, 15-28. https://doi.org/10.1016/j.agwat.2006.12.014

[10] Phogat, V., Malik, R.S. and Kumar, S. (2009) Modeling the Effect of Canal Bed Elevation on Seepage and Water Table Rise in a Sand Box Filled with Loamy Soil. Irrigation Science, 27, 191-200. https://doi.org/10.1007/s00271-008-0132-1

[11] Simunek, J. and Hopmans, J.W. (2009) Modeling Compensated Root Water and Nutrient Uptake. Ecological Modelling, 220, 505-521.

https://doi.org/10.1016/j.ecolmodel.2008.11.004

[12] Li, J. and Liu, Y. (2011) Water and Nitrate Distributions as Affected by LayeredTextural Soil and Buried Dripline Depth under Subsurface Drip Fertigation. Irrigation Science, 29, 469-478.

https://doi.org/10.1007/s00271-010-0255-Z

[13] Phogat, V., Mahadevan, M., Skewes, M. and Cox, J.W. (2012) Modeling Soil Water and Salt Dynamics under Pulsed and Continuous Surface Drip Irrigation of Almond and Implications of System Design. Irrigation Science, 30, 315-333. https://doi.org/10.1007/s00271-011-0284-2

[14] Phogat, V., Skewes, M.A., Cox, J.W. and Mahadevan, M. (2012) Modeling the Impact of Pulsing of Drip Irrigation on the Water and Salinity Dynamics in Soil in Relation to Water Uptake by an Almond Tree. WIT Transactions on Ecology and Environment, 168, 101-113. https://doi.org/10.2495/SI120091

[15] Phogat, V., Skewes, M.A., Cox, J.W. and Mahadevan, M. (2013) Evaluation of Soil Plant System Response to Pulsed Drip Irrigation of an Almond Tree under Sustained Stress Conditions. Agricultural Water Management, 118, 1-11. https://doi.org/10.1016/j.agwat.2012.11.015

[16] Phogat, V., Skewes, M.A., Cox, J.W., Alam, J., Grigson, G. and Simunek, J. (2013) Evaluation of Water Movement and Nitrate Dynamics in lysimeter Planted with an Orange Tree. Agricultural Water Management, 127, 74-84.

https://doi.org/10.1016/j.agwat.2013.05.017

[17] Ramos, T.B., Simunek, J., Goncalves, M.C., Martins, J.C., Prazeres, A., Castanheira, N.L. and Pereira, L.S. (2011) Field Evaluation of a Multicomponent Solute Transport Model in Soils Irrigated with Saline Waters. Journal of Hydrology, 407, 129-144. https://doi.org/10.1016/j.jhydrol.2011.07.016

[18] Ramos, T.B., Simunek, J., Goncalves, M.C., Martins, J.C., Prazeres, A. and Pereira, L.S. (2012) Two-Dimensional Modeling of Water and Nitrogen Fate from Sweet Sorghum Irrigated with Fresh and Blended Saline Waters. Agricultural Water 
Management, 111, 87-104. https://doi.org/10.1016/j.agwat.2012.05.007

[19] Kandelous, M.M. and Simunek, J. (2010) Comparison of Numerical, Analytical, and Empirical Models to Estimate Wetting Patterns for Surface and Subsurface Drip Irrigation. Irrigation Science, 28, 453-444. https://doi.org/10.1007/s00271-009-0205-9

[20] Andreas, P., Ines, B., Jean-Marc, F. and Gillet, V. (2008) Manuel des techniques d'irrigation sous pression. 2nd Edition, FAO, Rome.

[21] Simunek, J., Sejna, M. and Van-Genuchten, T.M. (2011) The HYDRUS-2D Software Package for Simulating the Two and Three-Dimensional Movement of Water, Heat, and Multiple Solutes in Variably-Saturated Media, Technical Manual, Version 2. PC Progress, Prague.

[22] Janssens, P., Diels, J., Vanderborght, J., Elsen, F., Elsen, A., Deckers, T. and Vandendriessche, H. (2015) Numerical Calculation of Soil Water Potential in an Irrigated “Conference” Pear Orchard. Agricultural Water Management, 148, 113-122. https://doi.org/10.1016/j.agwat.2014.09.023

[23] Seng, Y., Zhao, C., Feng, G., Yan, Y. and Seng, Y. (2015) Evaluating the Effects of Mulch and Irrigation Amount on Soil Water Distribution and Root Zone Water Balance Using HYDRUS-2D. Water Journal, 7, 2622-2640.

https://doi.org/10.3390/w7062622

[24] Kébré, M.B. (2013) Gestion des Ressources en Eau dans les Regions Arides : Analyse Expérimentale d'un Sol Type du Burkina Faso et Modélisation Numérique des Transferts d'Eau. Thèse de Doctorat, Civil Engineering, Université Montpellier II, France. 